\title{
ASSESSMENT OF SERVICE LIFE OF HCM12 STEEL AFTER 100000 HRS OF SERVICE
}

\begin{abstract}
The subject of the research was a material in the form of a $\phi 38 \times 4$ pipe from HCM12 steel used for steam superheater coils in power boilers with supercritical and ultra-supercritical steam parameters. This article presents results of investigations of mechanical properties and microstructure of material of the examined tube in the as-received condition and after 100,000 $\mathrm{h}$ service at $585^{\circ} \mathrm{C}$ under creep conditions. Creep tests were carried out for the material after $100,000 \mathrm{~h}$ service to determine the disposable residual life. The impact of changes in mechanical properties and degradation of the microstructure on the loss of creep resistance compared to the as-received condition was assessed. The investigations have revealed that the examined steel after $100,000 \mathrm{~h}$ service meets the requirements for this steel in the as-received condition with regard to strength properties at room and elevated temperature. The creep tests have revealed a significant loss of creep resistance, which was estimated at around $60-70 \%$ compared to the as-received condition.
\end{abstract}

Keywords: steel HCM12, creep, microstructure, mechanical properties, residual life

\section{Introduction}

The construction of boilers with supercritical steam parameters conducted from the end of the previous century has resulted in initiation of extensive research on steels for critical components of such boilers [1-4]. In particular, this concerns materials for components working under the toughest temperature and stress conditions. The effect of this research is the new-generation steels with required strength and technological properties. Depending on working conditions of boiler components made of this steel, they should be characterised, in addition to the required creep strength, by proper level of necessary plastic properties, weldability, adequately high scaling resistance and ability to perform technological processes on them. This set of characteristics was achieved by appropriate modification of chemical composition of these steels. For $9-12 \% \mathrm{Cr}$ steels, it was reduction in carbon content and introduction of, apart from molybdenum, the appropriate amount of alloying elements, such as vanadium, tungsten, nickel, copper, cobalt, and microadditions of nitrogen, boron and niobium (Fig. 1). Two main development trends can be distinguished for this group of steels. The first one concerns the modification of steels with $\mathrm{Cr}$ content of approx. $9 \%$ and the addition of Mo.

Due to the introduction of the additions of vanadium and tungsten and microadditions of nitrogen, boron and niobium, the P/T91, P/T92, NF616 and E911 steels were developed [5,6]. The second trend concerns the modification of steels with $\mathrm{Cr}$ content of $12 \%$ and the additions of Mo and V. The extra intro- duction of the additions of tungsten, nickel, copper or cobalt and microadditions of nitrogen, boron and niobium allowed the new NF12, TB12M, HCM12, HCM12A and VM12 steels to be developed $[7,8]$.

The very long time of waiting for results of functional properties after long-term exposure to temperature and stress, which are introduced into the operation of steels, forces, among other things, the application of extrapolation methods based on which long-term creep strength is estimated, often for 100 and 200 thousand hours [9]. In the majority of cases, the extrapolated creep strength values of the applied steels, additionally reduced by safety factors adopted in design calculations, allow safe operation of such components much beyond the design service life. It is connected with the so-called residual life understood as the difference of time between the real and design life of material. The methods for determination and sources of residual life are widely described in [9].

The investigations on HCM12 steel both in the as-received condition and after long-term exposure to elevated temperature, including changes in mechanical properties, corrosion processes and microstructural degradation processes, were the subject of numerous publications including, but not limited to [10-13]. However, they did not present issues related to degradation of microstructure and mechanical properties of this steel in relation to its real residual creep strength. This article presents results of investigations of mechanical properties and microstructure of HCM12 steel in the as-received condition with regard to their changes that took place in this steel after $100,000 \mathrm{~h}$ service at

\footnotetext{
INSTITUTE FOR FERROUS METALLURGY, 12-14 K, MIARKI STR, 44-100 GLIWICE, POLAND

** CZESTOCHOWA UNIVERSITY OF TECHNOLOGY, INSTITUTE OF MATERIALS ENGINEERING, 19 ARMII KRAJOWEJ AV., 42-200 CZESTOCHOWA, POLAND 
Creep strength for $100,000 \mathrm{~h}$ at temperature of $600^{\circ} \mathrm{C}$ and under stress:

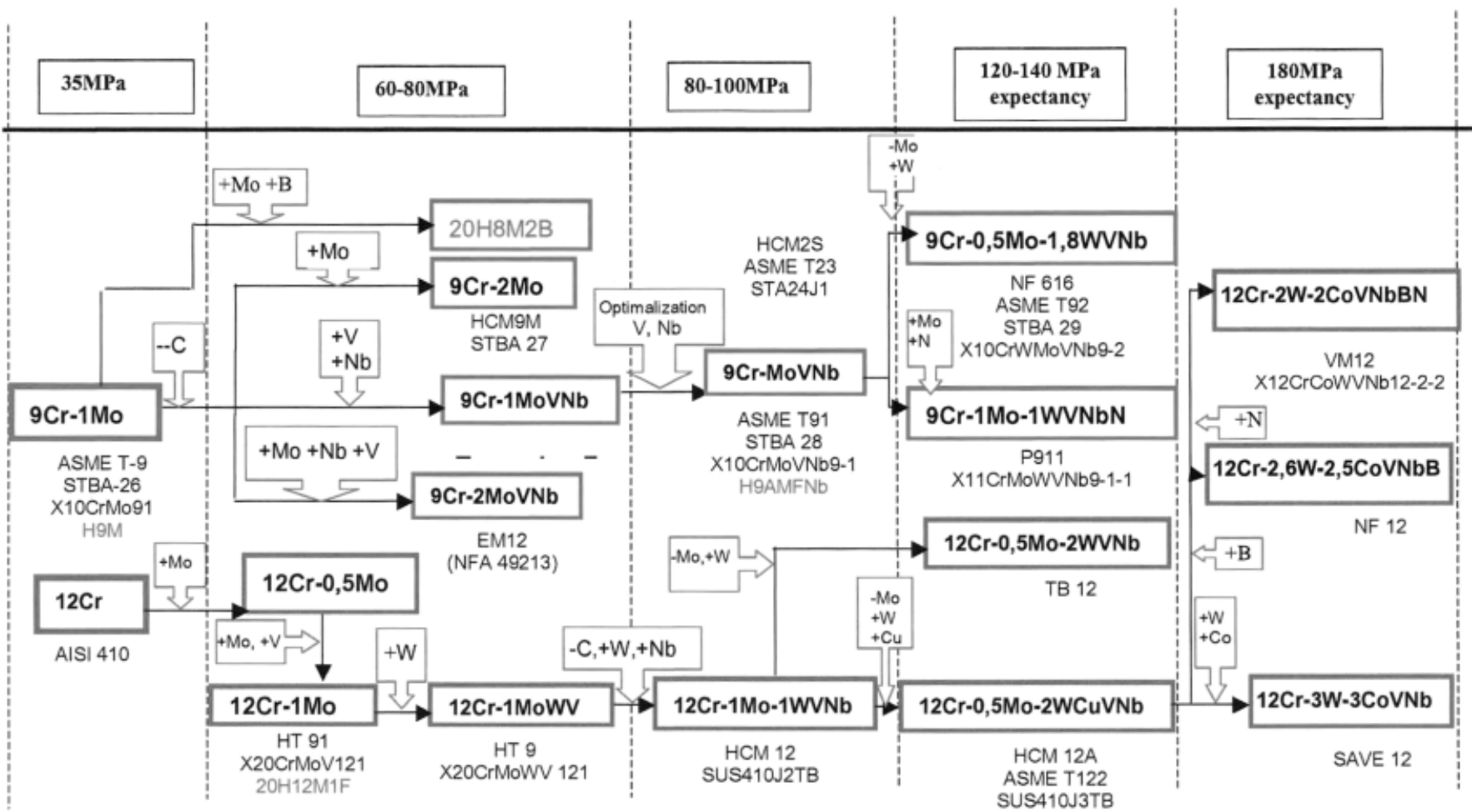

Fig. 1. Development alloy chromium steels including molybdenum for operation under creep conditions [1]

elevated temperature. The residual life and disposable residual life, i.e. the time of further safe service for the assumed operating parameters, determined based on abridged creep tests are also presented.

The abridged creep tests were used to determine the residual life and disposable residual life, which is the time of further safe operation for the assumed parameters of further service. The method for conducting and suitability of the abridged creep tests for determination of creep strength, for steels in the as-received condition as well as after long-term service, are described in [9,14-16].

The HCM12 steel is intended for steam superheater coils at the final degrees of overheat working at up to approx. $600^{\circ} \mathrm{C}$ and approx. $28 \mathrm{MPa}$ under creep conditions.

High-chromium $(9-12 \% \mathrm{Cr})$ martensitic steels are used in the quenched and tempered condition. The heat treatment of these steels consists of air quenching (in a part of the literature called normalising) followed by high-temperature tempering at above $720^{\circ} \mathrm{C}$. In its as-received state, the HCM12 steel is characterised by double-phase microstructure, i.e. tempered martensite and approx. 30\% of delta ferrite. The existence of delta ferrite in the microstructure of the examined steel results from predominance of the ferrite forming elements over the austenite forming ones. The lack of balance between these groups of elements results in delta ferrite stabilisation at high temperature $[4,10]$. The modification of chemical composition of HCM12 steel by adding copper, the austenite forming element, allowed the new grade of material to be obtained - HCM12A steel with a single-phase structure.

\section{Research material}

The material used in the research was two sections of HCM12 (12Cr-1Mo-1W-V-Nb) steel pipe with diameter of $\phi 38 \mathrm{~mm}$ and wall thickness of $4.0 \mathrm{~mm}$ The section in the asreceived condition was after normalising at $1030 \div 1050^{\circ} \mathrm{C} / 60$ min/air and tempering at $790 \div 820^{\circ} \mathrm{C} / 60 \mathrm{~min} /$ air. The second section of the tube was after $100.000 \mathrm{~h}$ service at $585^{\circ} \mathrm{C}$ under steam pressure of $21 \mathrm{MPa}$. The analysis of chemical composition of the examined steel compared to the requirements of VD-TÜW 510 [3] is summarised in Table 1.

TABLE 1

Chemical composition of the examined HCM12 pipe sections

\begin{tabular}{|c|c|c|c|c|c|c|c|c|c|c|}
\hline \multirow{2}{*}{ No. } & \multicolumn{10}{|c|}{ Chemical composition [\%] } \\
\cline { 2 - 10 } & $\mathbf{C}$ & $\mathbf{M n}$ & $\mathbf{P}$ & $\mathbf{S}$ & $\mathbf{S i}$ & $\mathbf{C r}$ & $\mathbf{M o}$ & $\mathbf{V}$ & $\mathbf{W}$ & $\mathbf{N b}$ \\
\hline $\begin{array}{c}\text { Test } \\
\text { material }\end{array}$ & 0.09 & 0.55 & 0.019 & 0.008 & 0.26 & 11.9 & 1.0 & 0.27 & 1.05 & 0.05 \\
\hline $\begin{array}{c}\text { VD-TÜW } \\
\text { 510 [13] }\end{array}$ & 0.14 & $\max$ & 0.30 & $\max$ & $\max$ & $\max$ & $11.0-$ & $0.80-$ & $0.20-$ & $0.80-$ \\
$\max$ \\
0.03 & 0.03 & 0.50 & 13.0 & 1.20 & 0.30 & 1.20 & 0.2 \\
\hline
\end{tabular}

\section{Methodology of research}

The of mechanical properties of HCM12 steel both in the as-received condition and after service included: static test of tension at room and elevated temperature using the testing machine under Zwick brand with its maximum load of $200 \mathrm{kN}$; measurement of hardness with Vickers method using the hardness tester Future - Tech FM - 7 with the indenter load of $10 \mathrm{kG}$. 
The abridged creep tests of the examined steels were carried out at the temperature of $620,640,660,680^{\circ} \mathrm{C}$ and test stress of 120 , 100 and $80 \mathrm{MPa}$ without the measurement of elongation during the test. The machine model used for creep tests was Instron M3TCS, ensuring the stability of temperature $\pm 0.5^{\circ} \mathrm{C}$ at the test temperature of up to $800^{\circ} \mathrm{C}$ within the test duration, using Programmable Logic Controller (PLC). The temperature was adjusted and measured using three sheathed thermocouples of type $\mathrm{S}$ and class 1, positioned on gauge length of the test sample. Microstructural tests were carried out with the use of scanning electron microscope Inspect F (SEM) on metallographic specimens etched with ferrous chloride and by means of transmission electron microscope TITAN 80-300 (TEM), using thin foils.

\section{Results of research and their discussion}

\subsection{Mechanical properties}

The investigation of mechanical properties was carried out for the material in the as-received condition and after 100,000 $\mathrm{h}$ service. The obtained results of investigations at 20, 550 and $600^{\circ} \mathrm{C}$ are presented as a diagram in Fig. 2.

The tensile strength TS and yield strength YS values for the material both in the as-received condition and after longterm service meet the requirements for this steel at both ambient temperature and a temperature similar to the operating one [17].

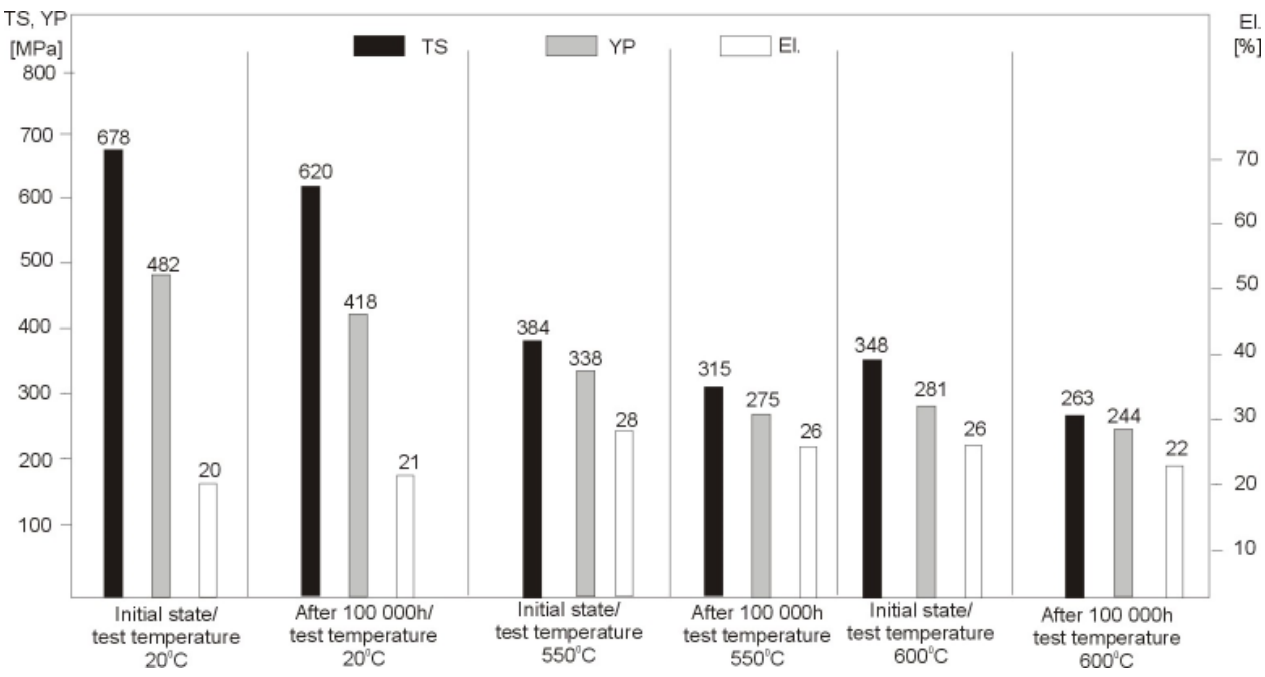

Fig. 2. The effect of long-term service on mechanical properties of HCM12 steel at ambient and elevated temperature

Based on the obtained results of investigations, it can be observed that the tensile strength TS and yield strength YS value was reduced to 9 and $13 \%$, respectively, due to long-term service for 100,000 thousand hours at ambient temperature. Similar changes were observed for tensile strength TS and yield strength YS at elevated temperature. At $500^{\circ} \mathrm{C}$, the TS and $\mathrm{YS}$ values were reduced by $18 \%$, while at $600^{\circ} \mathrm{C}$ the tensile strength TS and yield strength YS are lower by 24 and 14\%, respectively. A similar trend in reduction of strength properties was observed in [18] where the same material was investigated for 20 and 30 thousand h service.

\subsection{Microstructure of HCM12 steel in the as-received condition and after long-term service}

HCM12 steel in the as-received condition is characterised by the microstructure of tempered martensite containing approx. $30 \%$ of ferrite areas (Fig. 3a,b). Fine precipitates were observed mainly at the ferrite grain boundaries and at the martensite lath boundaries. The microstructural observations of HCM12 steel in the as-received condition with a transmission electron microscope (TEM) revealed the existence of the microstructure of high-tempered martensite with elongated sub-grains and di- verse dislocation density, and polygonised areas of sub-structure (Fig. 3c,d). The estimated dislocation density for the examined steel in the as-received condition was $1.82 \times 10^{14} \mathrm{disl} / \mathrm{m}^{2}$.

The microstructure of tempered martensite containing approx. $30 \%$ of delta ferrite is typical of this steel $[18,19]$. The identification of precipitates performed by selective electron diffraction revealed the existence of two types of precipitation in the as-received condition: i.e. $\mathrm{M}_{23} \mathrm{C}_{6}$ carbides and $\mathrm{MC}$ precipitates (Fig. 4 and 5). The $\mathrm{M}_{23} \mathrm{C}_{6}$ carbides were observed mainly at the former austenite grain boundaries and the martensite lath boundaries. The average diameter of $\mathrm{M}_{23} \mathrm{C}_{6}$ carbides and $\mathrm{MX}$ precipitates in HCM12 steel in the as-received condition was: $162 \pm 52 \mathrm{~nm}$ and $45 \pm 26 \mathrm{~nm}$, respectively.

The example images of microstructure of the examined steel after service are presented in Fig. 6. The microstructure observed with a scanning electron microscope (Fig. 6 a,b) differs from that in the as-received condition. A noticeable difference in steel after service compared to that in the as-received condition was the increase in the size and amount of precipitates at the boundaries of and inside ferrite grains and at the martensite lath boundaries. A significant disappearance of martensite lath microstructure was observed too. In places, the precipitates at the boundaries formed the so-called continuous network of precipitates. 
1024
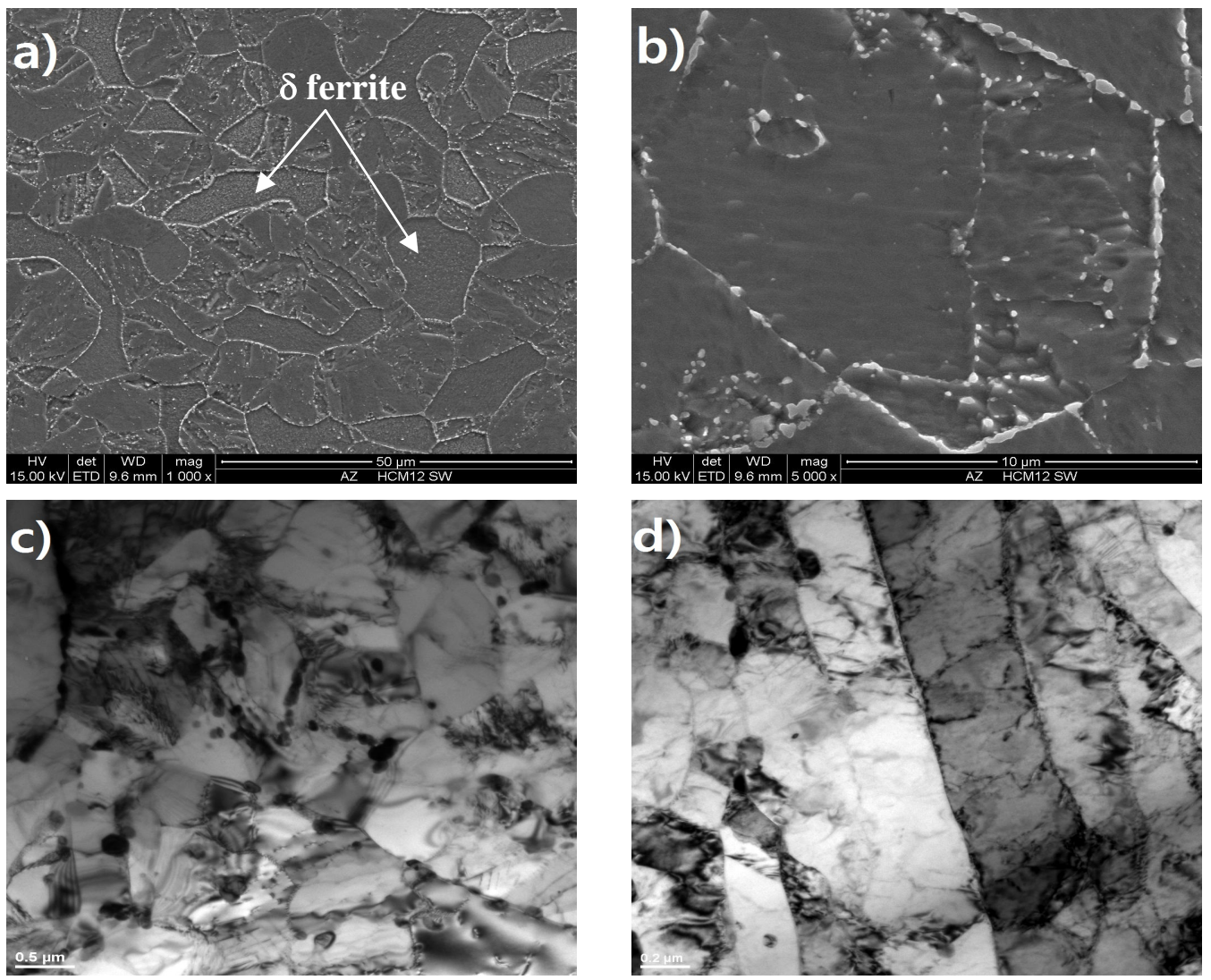

Fig. 3. Microstructure of HCM12 steel in the as-received condition: a,b) observed in SEM, c,d) observed in TEM. Hardness 221 HV10
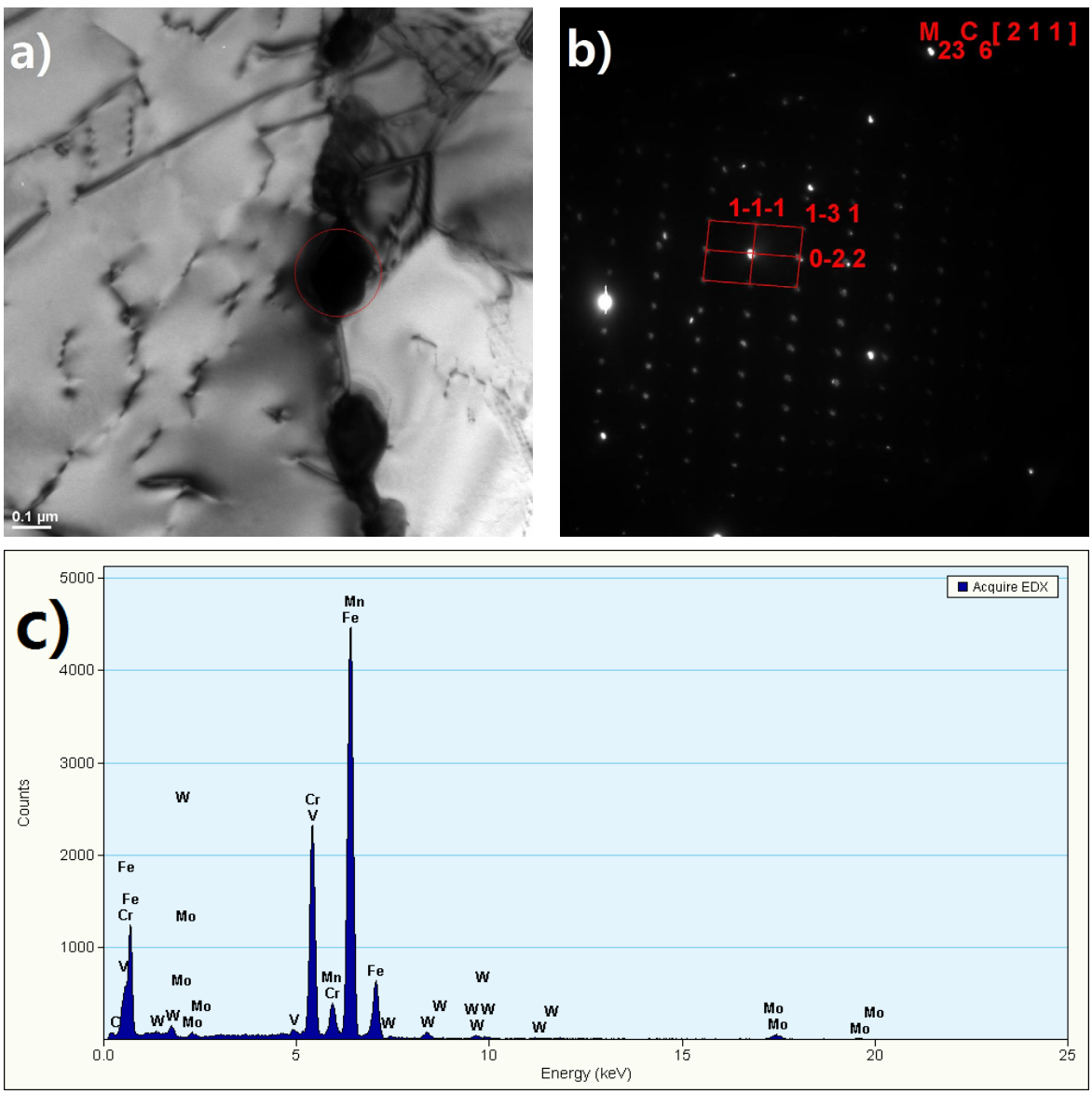

Fig. 4. $\mathrm{M}_{23} \mathrm{C}_{6}$ carbide in HCM12 steel in the as-received condition: a) dark field, b) solved diffraction pattern, c) EDS spectrum from phase analysis, TEM 


\section{$\underbrace{\text { PAn }}_{\text {PAN }}$}
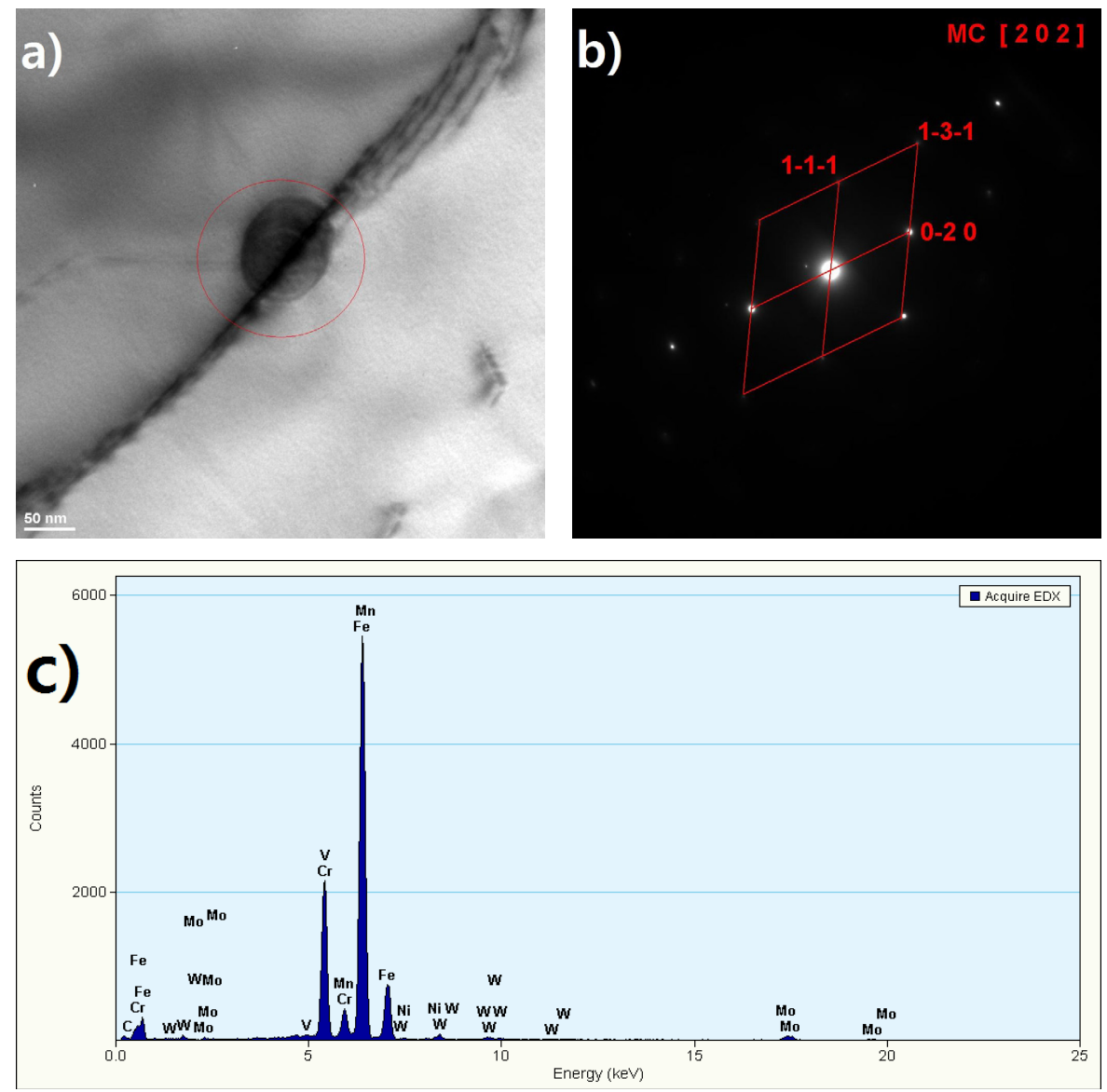

Fig. 5. Niobium-rich MC precipitate in HCM12 steel in the as-received condition: a) dark field, b) solved diffraction pattern, c) EDS spectrum from phase analysis, TEM
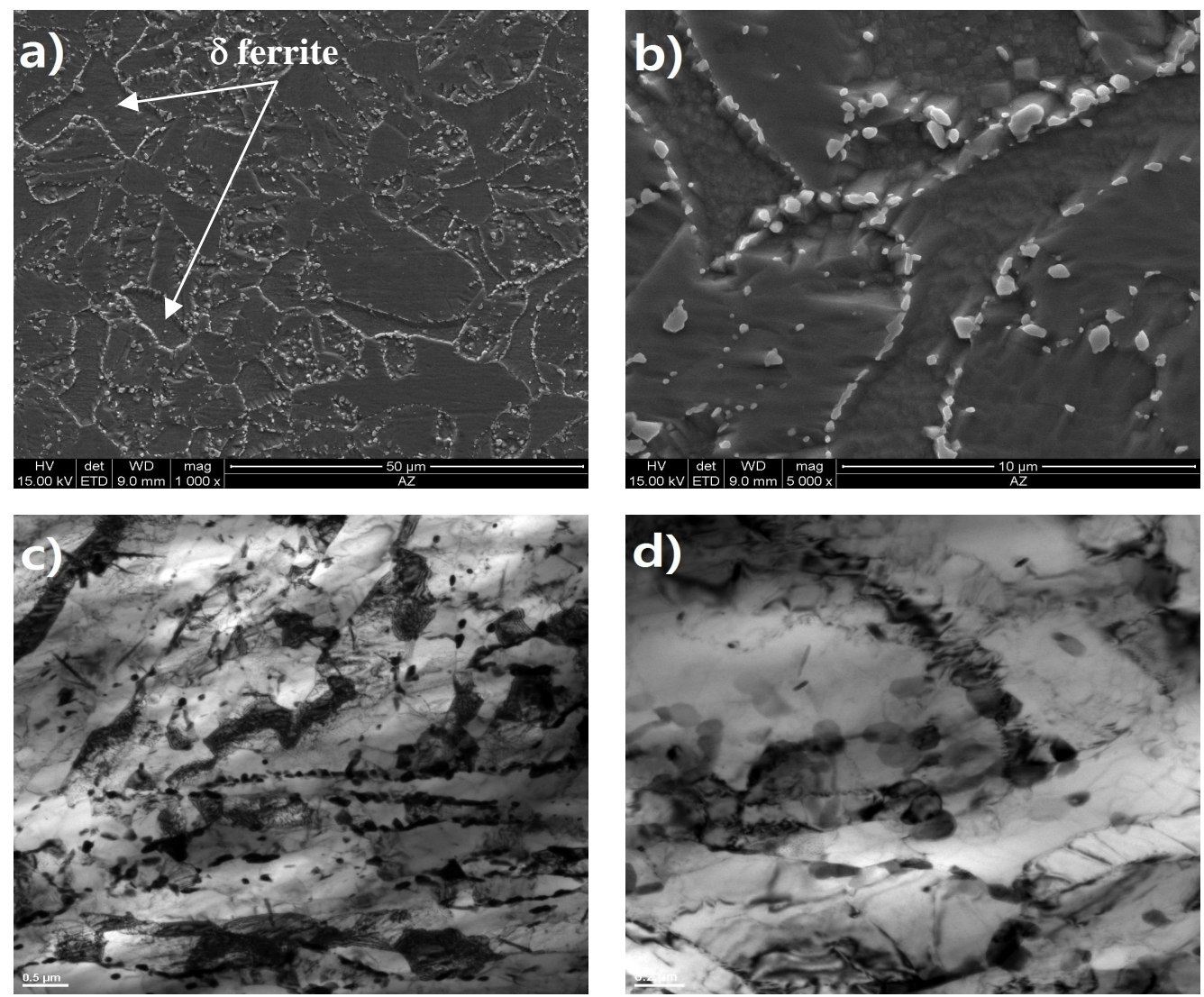

Fig. 6. Microstructure of $\mathrm{HCM} 12$ steel after service at $585^{\circ} \mathrm{C}$, a,b) SEM, c,d) TEM. Hardness $187 \mathrm{HV} 10$ 
In the microstructure observed in TEM (Fig. 6 c,d), only a partially preserved martensite lath microstructure was observed. The matrix recovery and polygonisation processes were visible too. In addition to $\mathrm{M}_{23} \mathrm{C}_{6}$ carbides (Fig. 7) and $\mathrm{MX}$ precipitates (Fig. 8), the identifications of precipitates in steel after long-term service also revealed the precipitation of Laves phase (Fig. 9). The diffusion processes that occur during service favour the continuous process of ordering and annihilation of dislocation within the boundaries, which results in reduction in their density. After service, the estimated dislocation density in the examined steel was $0.39 \times 10^{14} \mathrm{disl} / \mathrm{m}^{2}$.

The average diameter of $\mathrm{M}_{23} \mathrm{C}_{6}, \mathrm{MX}$ and Laves phase precipitates after service was: $214 \pm 98 \mathrm{~nm}, 67 \pm 28 \mathrm{~nm}$ and 412 $\pm 87 \mathrm{~nm}$, respectively.
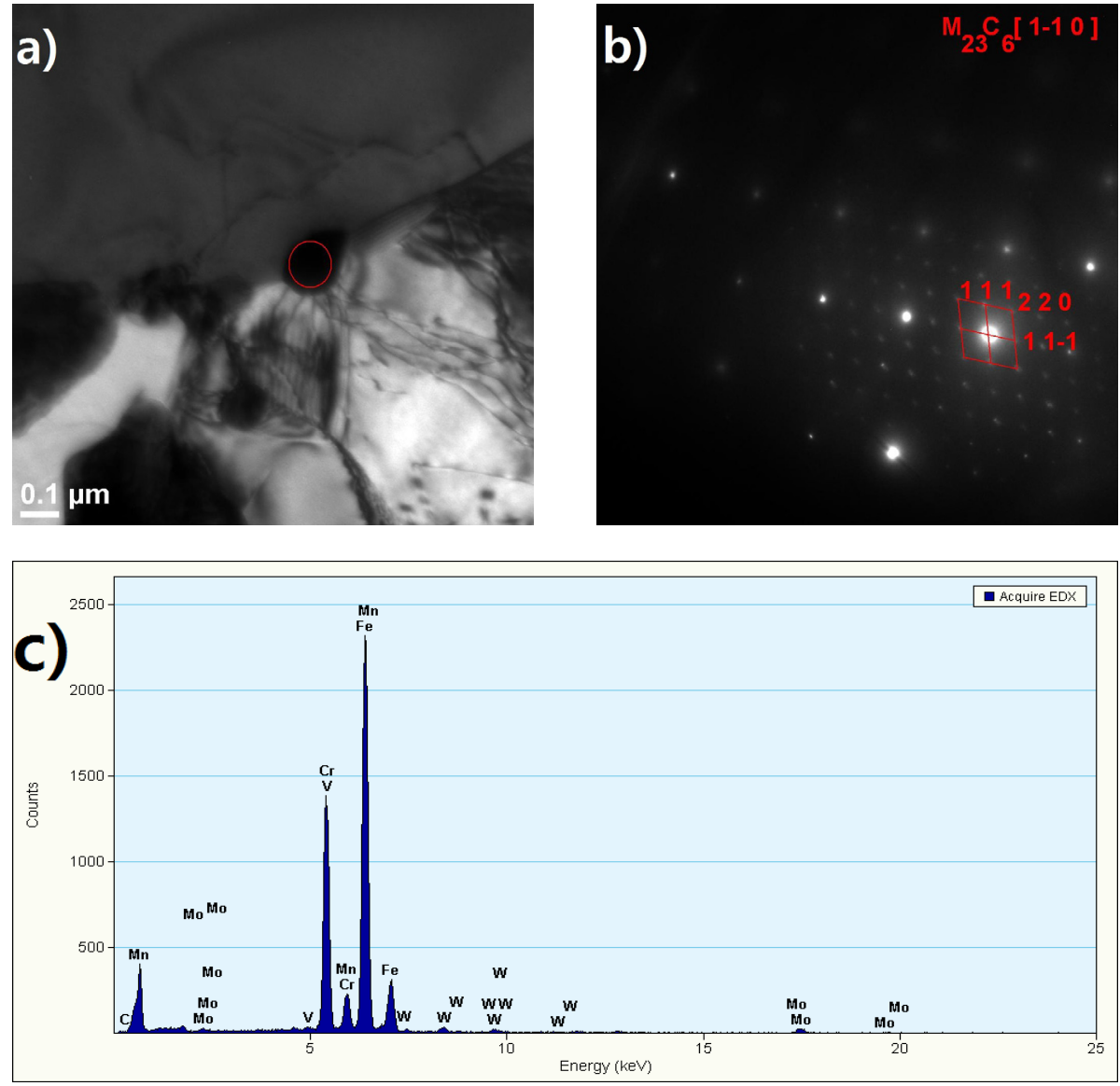

Fig. 7. $\mathrm{M}_{23} \mathrm{C}_{6}$ carbides in HCM12 steel after service: a) microstructure, b) solved diffraction pattern, c) EDS spectrum from phase analysis

\subsection{Creep tests - determination of residual life for HCM12 steel}

Out of the estimated mechanical properties, the most significant and decisive to the suitability of specific material for transferring loads during service is creep test. It is a timeconsuming test, and the time of waiting for its results is minimum a few years. The acceleration of creep is obtained by elevating test temperature above the values under operating conditions, while keeping stresses at a level similar to the operating one. The duration of these tests is the time to rupture of a test piece made of the examined material. The obtained test results allow the residual life and disposable residual life to be determined and are the basic source of information for evaluation of forecasting the time of safe operation of materials. Such a method for conducting creep tests was verified based on long-term creep tests, and the results of examinations were the subject of numerous publications [14-16,20,21]. The obtained results of abridged creep tests for HCM12 steel after service are presented graphically in Fig. 10.

The obtained test results (Fig. 10) allowed the residual life of HCM12 steel after service to be determined by graphical extrapolation method for three levels of test stress $\sigma_{b}=80,100$ and $120 \mathrm{MPa}$ and temperature 580,590 and $600^{\circ} \mathrm{C}$ (Table 2).

TABLE 2

Residual life determined for HCM12 steel after service

\begin{tabular}{|c|c|c|}
\hline \hline Test stress s, MPa & Temperature, ${ }^{\circ} \mathbf{C}$ & Residual life, $\mathbf{h}$ \\
\hline 80 & 580 & $\sim 23000$ \\
\hline 80 & 590 & $\sim 10000$ \\
\hline 80 & 600 & $\sim 5000$ \\
\hline 100 & 580 & $\sim 4300$ \\
\hline 100 & 590 & $\sim 2000$ \\
\hline 100 & 600 & $\sim 1000$ \\
\hline 120 & 580 & $\sim 700$ \\
\hline 120 & 590 & $\sim 250$ \\
\hline 120 & 600 & $\sim 105$ \\
\hline
\end{tabular}




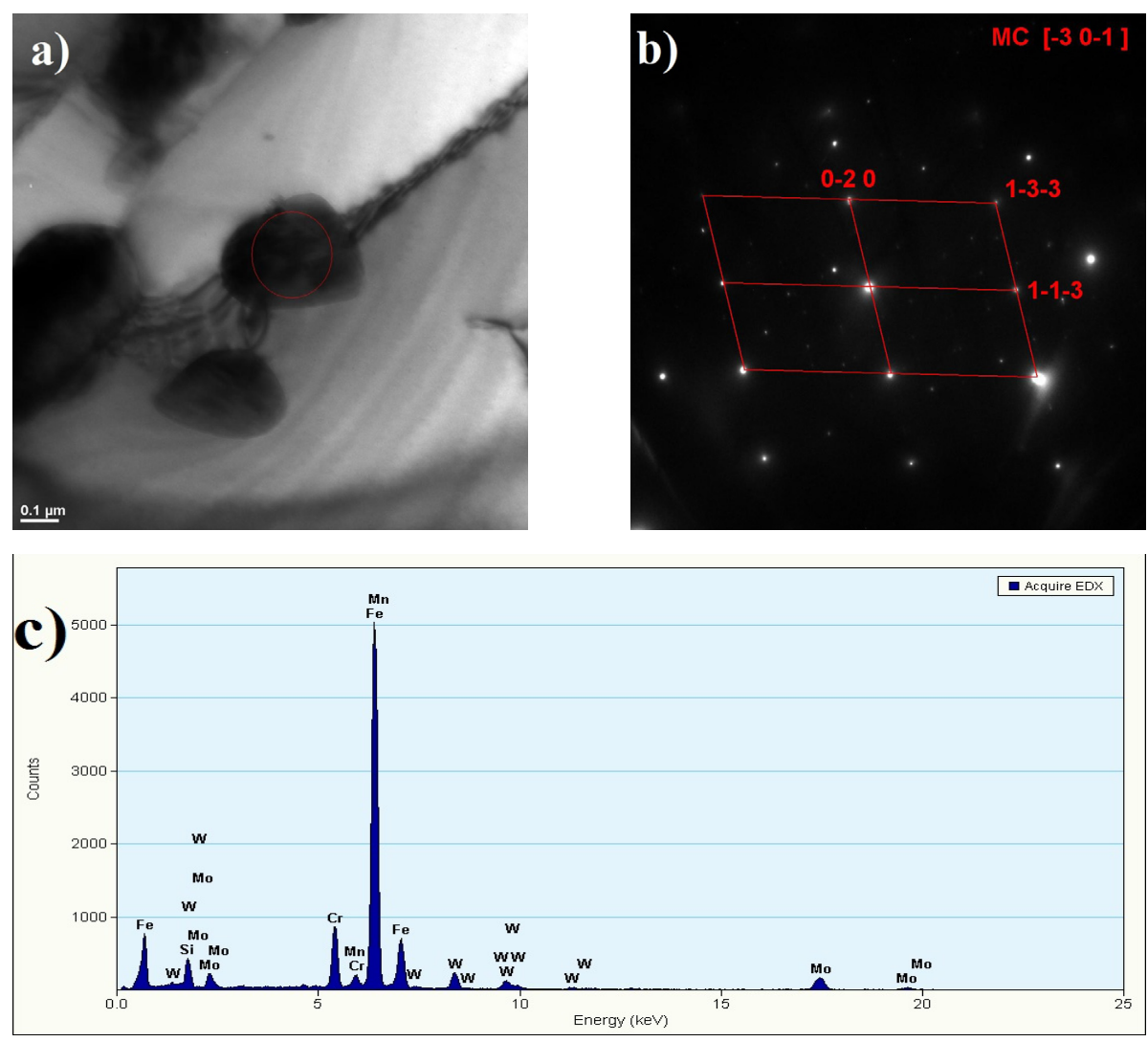

Fig. 8. MC carbides in HCM12 steel after service: a) microstructure, b) solved diffraction pattern, c) EDS spectrum from phase analysis
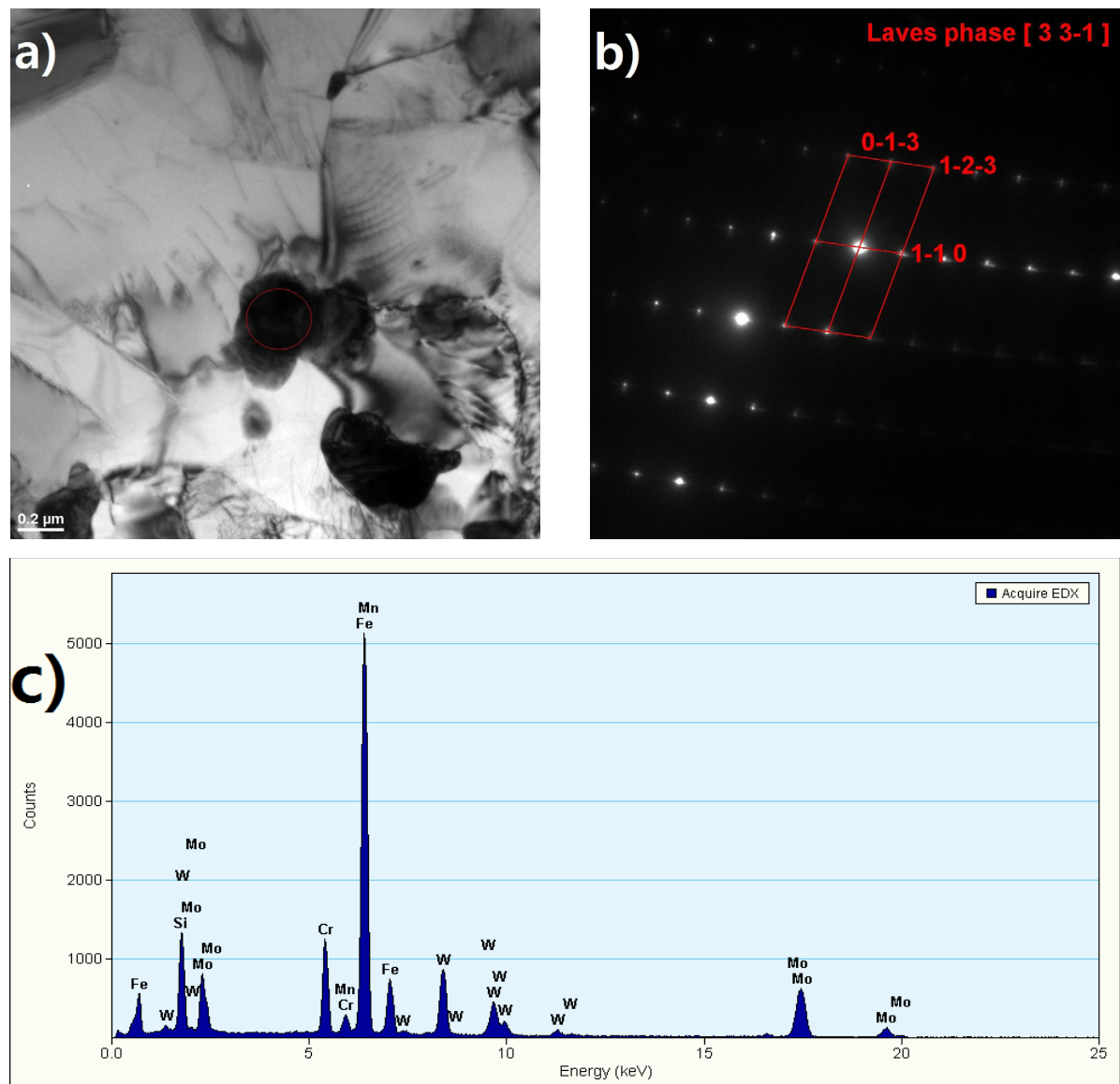

Fig. 9. Precipitation of Laves phase in HCM12 steel after service; b) solved diffraction pattern, c) EDS spectrum from phase analysis, TEM 


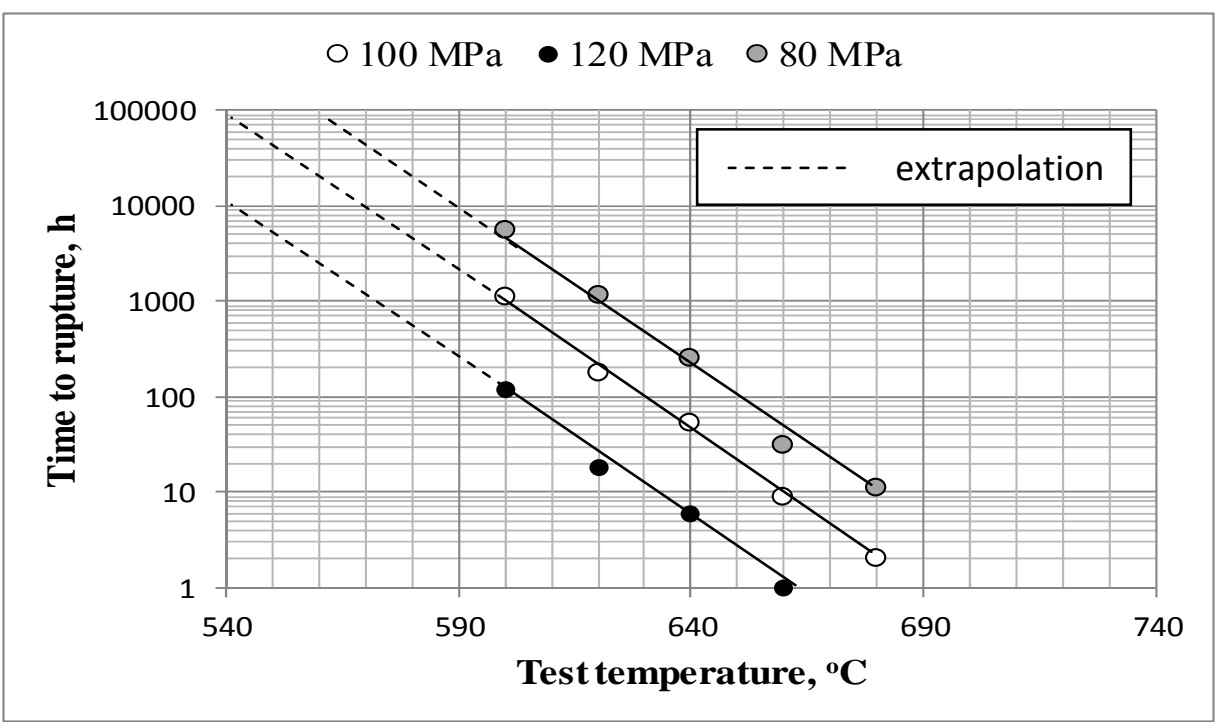

Fig. 10. Results of abridged creep tests for material of $\phi 38 \times 4$ pipe after $100,000 \mathrm{~h}$ service at $585^{\circ} \mathrm{C}$

Based on the residual life, the creep strength characteristics were developed for the temperature of 580,590 and $600^{\circ} \mathrm{C}$, which is shown in Fig. 11, and creep strength $R_{z / 10000}$ and $R_{z / 100000}$ was determined (Table 3).
The obtained stress values for the service time of $10^{4}$ and $10^{5} \mathrm{~h}$ and temperature of 580,590 and $600^{\circ} \mathrm{C}$ were compared to the creep strength values determined for HCM12 steel in the as-received condition.

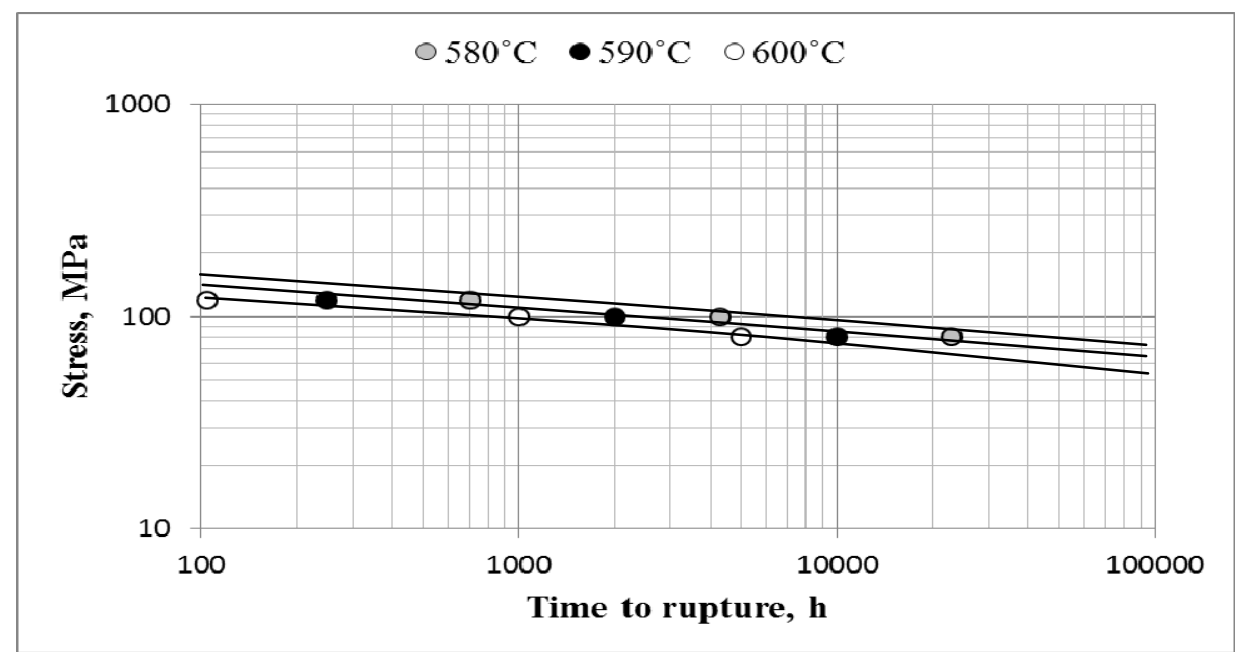

Fig. 11. Creep strength of HCM12 steel after $100,000 \mathrm{~h}$ service for test temperature $\mathrm{T}_{\mathrm{b}}=580,590$ and $600^{\circ} \mathrm{C}$

TABLE 3

Residual creep strength determined for HCM12 steel after service compared to the results for material in the as-received condition

\begin{tabular}{|c|c|c|c|}
\hline \hline \multirow{2}{*}{ Creep strength } & $\begin{array}{c}\text { As-received } \\
\text { condition [17] }\end{array}$ & $\begin{array}{c}\text { After } \\
\text { service }\end{array}$ & Difference \\
\cline { 2 - 4 } & Stress s, MPa & Stress s, $\mathbf{M P a}$ & $\%$ \\
\hline $\mathrm{R}_{\mathrm{z} / 10000 / 580^{\circ} \mathrm{C}}$ & 228 & 90 & 61 \\
\hline $\mathrm{R}_{\mathrm{z} / 100000 / 580^{\circ} \mathrm{C}}$ & 126 & 50 & 60 \\
\hline $\mathrm{R}_{\mathrm{z} / 10000 / 590^{\circ} \mathrm{C}}$ & 212 & 80 & 62 \\
\hline $\mathrm{R}_{\mathrm{z} / 100000 / 590^{\circ} \mathrm{C}}$ & 111 & 44 & 60 \\
\hline $\mathrm{R}_{\mathrm{z} / 10000 / 600^{\circ} \mathrm{C}}$ & 197 & 70 & 64 \\
\hline $\mathrm{R}_{\mathrm{z} / 100000 / 600^{\circ} \mathrm{C}}$ & 98 & 30 & 69 \\
\hline
\end{tabular}

The tests revealed that the examined steel was characterised by reduction in creep strength by approx. $60-70 \%$ compared to the as-received condition. This indicates a significant degree of degradation of the microstructure for the examined steel after service.

\section{Summary}

The research concerned high-chromium martensitic steel $\mathrm{HCM} 12$ after $100,000 \mathrm{~h}$ service at $585^{\circ} \mathrm{C}$ and under pressure of $21 \mathrm{MPa}$. In its as-received condition, the examined steel was characterised by microstructure of high-tempered martensite with 
numerous $\mathrm{M}_{23} \mathrm{C}_{6}$ and $\mathrm{MX}$ precipitates containing approx. 30\% of ferrite $\mathrm{d}$, which is typical of this grade. Long-term service has caused significant changes in the microstructure of HCM12 steel. The degradation of microstructure of the examined steel was a significant disappearance of martensite lath microstructure, increase in the size of precipitates and precipitation of unfavourable Laves phase. The investigations on properties of HCM12 steel in the as-received condition and after service have confirmed that the values of strength properties (YS, TS) both at room and elevated temperature were reduced. However, the obtained results are higher than the minimum ones required for this steel grade. Compared to the as-received condition of the examined steel, the values of its hardness after service were reduced by $15 \%$.

The abridged creep tests allowed the residual creep strength of HCM12A steel after service to be determined. The estimated loss of creep strength due to long-term service for the examined steel is approx. $60-70 \%$.

\section{Acknowledgements}

The results in this publication were obtained as a part of research co-financed by the National Centre for Research and Development under contract PBS3/ B5/42/2015 - Project: "Methodology, evaluation and forecast of operation beyond the analytical operating time of welded joints of pressure components of power bollers".

\section{REFERENCES}

[1] F. Masuyama, $6^{\text {th }}$ Int. Conf. on Materials for Advanced Power Engineering, Belgium 1998.

[2] R. Viswanathan, J.F. Henry, J. Tanzosh, G. Stanko, J. Shingledekker, B. Vitalis, R. Purgert, J. Mater. Eng. Perform. 14 (3), 281-292 (2005).

[3] P.J. Ennis, A. Czyrska-Filemonowicz, Sadhana-Acad. P. Eng. S. 28 (3-4), 709-730 (2003).
[4] V. Sklenička, K. Kuchařová, M. Svoboda, L. Kloc, J. Buršı, A. Kroupa, Mater. Charact. 51 (1), 35-48 (2003).

[5] A. Zieliński, G. Golański, M. Sroka, Kovove Mater. 54 (1), 61-70 (2016).

[6] Data Package for NF616 Ferritic Steel (9Cr-0,5Mo-1,8W-Nb-V), Nippon Steel.

[7] NIMS Creep date sheet No43 Data Sheets on the elevated temperature properties of $9 \mathrm{Cr}-1 \mathrm{Mo}-\mathrm{V}-\mathrm{Nb}$ steel for power boilers (ASME SA-213/SA-213M Grade T91). NIMS, Japan 1996.

[8] NIMS Creep date sheet No48 Data Sheets on the elevated temperature properties of $9 \mathrm{Cr}-0,5 \mathrm{Mo}-1,8 \mathrm{~W}-\mathrm{V}-\mathrm{Nb}$ steel tube for power boilers (ASME SA-213/SA-213M Grade T92). NIMS, Japan 2002.

[9] J. Dobrzański, Open Access Library, Materials science interpretation of the life of steels for power plants, Gliwice 2011.

[10] K. Rodak, A. Hernas, A. Kiełbus, Mater. Chem. Phys. 81 (2), 483-485 (2003).

[11] M. Igarashi, 12Cr-1Mo-1W-V-Nb steel, in: K. Yagi, G. Merckling, T.U. Kern, H. Irie, H. Warlimont, (Eds.), Springer Berlin Heidelberg 2004.

[12] J. Hald, Int. J Pres. Ves. Pip. 85 (1), 30-37 (2008).

[13] K. Rodak, A. Hernas, Sol. St. Phen. 212 , 25-28 (2014).

[14] A. Zieliński, G. Golański, M. Sroka, T. Tański, Mater. High Temp. (2015), DOI: 10.1179/1878641315Y.0000000015 (in press).

[15] A. Zieliński, M. Miczka, M. Sroka, Mater. Sci. Tech-Lond. (2016), DOI: 10.1080/02670836.2016.1150242, (in press).

[16] A. Zieliński, G. Golański, M. Sroka, J. Dobrzański, Mater. Sci. Tech-Lond. (2015), DOI: 10.1179/1743284715Y.0000000137 (in press).

[17] Vd TÜW Wekstoffblatt nr 510 - Warmfester Stahl HCM12, 1994.

[18] A. Hernas, G. Moskal, K. Rodak, J. Pasternak, J. Achiev. Mat. Manuf. Eng. 17 (1-2), 69-72 (2006).

[19] J. Brózda, Weld. Int. 19 (8), 593-599 (2005).

[20] A. Zieliński, J. Dobrzański, H. Purzyńska, G. Golański, Mater. Test. 57, 859-865 (2015).

[21] O. Kanemaru, M. Shimizu, T. Ohba, H. Miyazaki, F. Abe, K. Yagi, Mater. Sci. Res. Inter. 3, 31-36 (1997). 